\title{
Chemical Composition of Sudanese Burgers and Their Impact on Health as Nutrients
}

\author{
Ezzeldein M. Yagoup ${ }^{1}$, Alsiddig Osama ${ }^{2,}$, Nagat A. Elrofaei $^{3}$, Omer A. M. Goda ${ }^{2}$ \\ ${ }^{1}$ Department of Nutrition, Faculty of Science and Technology, Omdurman Islamic University, Khartoum, Sudan \\ ${ }^{2}$ Department of Chemistry, Faculty of Science and Technology, Omdurman Islamic University, Khartoum, Sudan \\ ${ }^{3}$ Biotechnology Department, Faculty of Science and Technology, Omdurman Islamic University, Khartoum, Sudan
}

\section{Email address:}

alsiddigosama@gmail.com (A. Osama)

${ }^{*}$ Corresponding author

\section{To cite this article:}

Ezeldin Yagope, Alsiddig Osama, Nagat A. Elrofaei, Omer A. M. Goda. Chemical Composition of Sudanese Burgers and Their Impact on Health as Nutrients. Journal of Food and Nutrition Sciences. Vol. 5, No. 3, 2017, pp. 69-72. doi: 10.11648/j.jfns.20170503.12

Received: February 8, 2017; Accepted: February 20, 2017; Published: April 14, 2017

\begin{abstract}
The main objective of this study, is determining the chemical composition of Sudanese burgers produced in different processing plants (modern processing lines, medium processing lines, and traditional processing lines). The study considered the role of raw materials used in processing (raw meat, spices, soybean flour, bread crumbs and water). Analysis of the final products to determine their content in (moisture, protein, ash, total fats, fatty acids, and minerals). The study showed significant differences with respect to chemical and physical properties, where the burger B-medium processing line recorded higher mean value of moisture content, iron, sodium and magnesium, and the lower mean value of fat and protein, while burger C-traditional processing line recorded higher mean value of ash content, myristic acid, while burger A-modern processing line recorded highest mean value of phosphorus, potassium, calcium, oleic acid and palmitic acid. The variation could be due to the type of raw materials used during processing. The study revealed that, the burger contains high percentage of saturated fatty acids which represent a potential hazard to human health.
\end{abstract}

Keywords: Sudanese Burger, Nutrients, Minerals, Fatty Acid

\section{Introduction}

Beef burger is made of meat, which is a valuable contributor to the diets of people in all the globe. Because its good source of proteins needed for the production of new tissues and regulation of physiological process in our bodies, beside it is a major source of amino acids, it also provides our bodies with a considerable amount of fat, which is an important source of energy $8.5 \mathrm{cal} / \mathrm{g}$. beside the energy aspect the fat of meat, is important for essential fatty acids and for fat soluble vitamins, A, D, E and $\mathrm{K}$. and that is also indispensable for sensory aspect of flavor and culinary use. The digestibility varies depending on the fatty acids constituent of the meat. The beef burger also contains water soluble vitamins, riboflavin, nicotinamide, thiamine, pentathonic acid, folic acid, cobalamine, and traces of vitamin C [1]. Mostly all mineralsvital to humans are present in meat. Meat are significantsource of iron and about 40 to $60 \%$ of iron from meat is highly absorbable [2]. Other minerals sodium, potassium, phosphors, zinc and magnesium. Minerals are inorganic substances, present in all body tissues and fluids and their presence is necessary for the maintain of certain physiochemical process that are essential to life. Although they yield no energy, they have important role to play in many activities in the body [3].

Burger is processed meat. The processing includes all process that alter fresh meat, this includes the addition of certain additives, which modify the properties of fresh meat, this include chilled water or ice to dissolve sodium chloride and imparts fluidity to the meat mixture that aids in proper filing of casing, tenderness of the finished burger is markedly affected by the added water content [4]. The second additive is salt, used in meat processing and 
contributes to basic taste characteristic of the final product it's usually ranges from 1.5 to $2.2 \%$. apart from improving the taste, the combination of salt with water assists in opening up the structure of protein [5]. Sodium chloride is an important ingredient in the meat industry [6]. The third additive is sugar, used to mask the salt flavor and nonreducing sugar can be used where browning is undesirable [4]. The fourth additive are spices, defined as any aromatic vegetable substances used to add flavor to the burger and also affect the consisting of ground mixture. At last we arrive to the usage of benders and extenders, these are wide Varity of non-meat products, which can be incorporated into burger within the guideline allowed under meat inspection regulations, they are added to reduce formulation loses, improve cooking yields, improve emulsion stability, increase the protein content, improve fat binding, increase water binding, and finally improve flavor. The content of these materials in products are controlled by meat inspection regulation. Individually or collectively up to $3.5 \%$ of cereal starch, textured vegetables product, concentrated soya protein, dry milk skimmed [4]. There are several potentials chemical hazards that can be present in meat products, such as heavy metals contaminants, chemical solvents, cleaning and ventilating compounds, residues of veterinary drugs, feed additives, pesticides, food additives, risk of overdoses of nitrate, nitrites or chemical preservatives [7].

\section{Materials and Methods}

All chemicals used were of analytical reagent grade (AR) and of highest purity degree available. They included magnesium nitrate hexahydrate, nitric acid, methanol, nhexane, distilled water and deionized water. All tests were triplicated 3 times and standard deviation was taken.

\subsection{Moisture Content}

Accurately $5 \mathrm{~g}$ of burger representative sample was pit in a preweighed porcelain dish, heated in a drying oven at $105^{\circ} \mathrm{C}$ for 2 hours, deride in a desiccator and weighed to constant value, with sensitive analytical balance and determined as percentage.

$$
\begin{gathered}
\text { Moisture content }=(\Delta \mathrm{W} / \mathrm{Ws}) \mathrm{X} 100 \\
\Delta \mathrm{W}=\text { loss in weigh, ws }=\text { weigh of sample }
\end{gathered}
$$

\subsection{Total fat Content}

This test was done with a soxhlet extraction [8], $10 \mathrm{~g}$ of the finished product were placed in a thimble, heated gently in a soxhlet extraction for 10 hours using n-hexane as a solvent. The fat was isolated form solvent by a rotary evaporator.

$$
\text { Fat content }=(\Delta \mathrm{W} / \mathrm{Ws}) \mathrm{X} 100
$$

\subsection{Fatty Acids Composition}

The methyl esters of fatty acids were prepared from aliquots of total lipids using $5 \mathrm{ml} \mathrm{H}_{2} \mathrm{SO}_{4}(3 \%)$ in absolute methanol and $2 \mathrm{ml}$ benzene as mentioned by the A.O.C.S [9]. The content was heated for methanolysis at $90^{\circ} \mathrm{C}$ for 90 minute and after cooling, phase separation was performed by addition of $2 \mathrm{ml}$ distilled water and methyl ester were extracted with $2 \mathrm{ml}$ aliquots of $5 \mathrm{ml}$ hexane each. The organic phase was removed, filtered through anhydrous sodium sulfate and then concentrated by using rotary evaporator. The methyl esters of fatty acids were separated using PYE Unicam Pro-GC, gas liquid chromatography with dual flame ionization, peak identification were established by comparing the retention time obtained with standard methyl esters. The areas under the chromatographic peak were measured with electronic integrator.

\subsection{Protein Content}

Total nitrogen (TN) was determined according to the A.O.A.C. [10]. $1 \mathrm{~g}$ sample was placed in a pre-weighed beaker, few $\mathrm{ml}$ of distilled water was added and then cautiously equal amount of pure nitrogen free sulphuric acid were added, stirred gently. The contents were transferred to Kjelahl flask and sulphuric acid was added up to $25 \mathrm{ml}, 2 \mathrm{~g}$ of $\mathrm{K}_{2} \mathrm{SO}_{4}$ and $0.3 \mathrm{~g}$ of copper sulphate were added. The flask was heated over flame for 30 minute until the liquid became clear and then cooled. $50 \mathrm{ml}$ of distilled water were added. The distillate was collected in $25 \mathrm{ml}$ of boric acid solution together with methyl red and bromocresol green as indicators. Titrated against $1 \mathrm{~N} \mathrm{HCl}$.

$$
\begin{gathered}
\text { Total nitrogen }(\mathrm{TN})=(\mathrm{TXNX} 0.014 \mathrm{X} 100) /(\text { wt of sample }) \\
\% \text { (3) } \\
\% \text { crude protein }=\mathrm{TNX} 6.25
\end{gathered}
$$

Where $\mathrm{T}=$ volume of titration, $\mathrm{N}=$ normality of $\mathrm{HCl}$

\subsection{Total Ash Content}

$5 \mathrm{~g}$ of burger sample was placed into a vycor crucible, 2.5 $\mathrm{ml}$ of $50 \%(\mathrm{w} / \mathrm{v}) \mathrm{Mg}\left(\mathrm{NO}_{3}\right)_{2} \cdot 6 \mathrm{H}_{2} \mathrm{O}$ were added and pre-ashed for 2 hours until the sample is completely charred under an infrared lamp on a hot plate, then transferred to muffle furnace and ashed at $500^{\circ} \mathrm{C}$ for an hour.

$$
\text { Ash content } \%=(\text { weigh of ash } \mathrm{X} 100) / 5
$$

\subsection{Mineral Contents}

They were determined according to Uddin, 2016 [11]. The ash from above was wetted by $\mathrm{HNO}_{3}$ and put in the furnace for 2 hours. The crucible was washed with $1 \mathrm{ml} \mathrm{HNO}_{3}$ (conc.), then two $1 \mathrm{ml}$ portion of dilute $\mathrm{HNO}_{3}$. All the washing was transferred to $10 \mathrm{ml}$ volumetric flask, diluted to volume with deionized water. The minerals were determined by atomic absorption spectrophotometry. 


\section{Results and Discussion}

The experiments done revealed the amount of moister, protein and fat content of burger as shown in table (1).

Table 1. Mean value $\pm S D$. of moister, protein and fat contents for burger samples from different processing plants.

\begin{tabular}{llll}
\hline $\begin{array}{l}\text { Determined } \\
\text { substance }\end{array}$ & \multicolumn{3}{l}{ Type of burger processing plants } \\
\cline { 2 - 4 } & A & B & C \\
\hline $\begin{array}{l}\text { Moister content } \\
(\%)\end{array}$ & $60.68 \pm 0.59$ & $62.20 \pm 0.87$ & $61.23 \pm 0.90$ \\
$\begin{array}{l}\text { Crude protein } \\
(\%)\end{array}$ & $21.81 \pm 0.54$ & $20.81 \pm 0.62$ & $21.26 \pm 0.86$ \\
Fat content $(\%)$ & $7.85 \pm 0.07$ & $6.72 \pm 0.04$ & $7.79 \pm 0.26$ \\
\hline
\end{tabular}

$\mathrm{A}=$ modern processing plants, $\mathrm{B}=$ medium processing plants, $\mathrm{C}=$ traditional processing plants.

The results showed the moister percentage was higher in the traditional processing plants than the others, due to the larger amount of water added during processing. The A process constituted higher percentage of protein and this may be due to the added ingredients namely the soy protein. Data in table (1) show high fat content for burger A, which may be attributed to the low moister content. However, Mahmoud and Badr, 2011 [12], reported that the soy protein plays a significant role in the modification of the functional characteristics of meat product, it can also be used to replace part of the animal fat.

Table 2. Mean values of ash content and some minerals for burger samples from different processing plants $(\mathrm{mg} / 100 \mathrm{~g})$.

\begin{tabular}{llll}
\hline \multirow{2}{*}{ Determined metal } & \multicolumn{4}{l}{ Type of burger processing plants } \\
\cline { 2 - 4 } & $\mathbf{A}$ & $\mathbf{B}$ & $\mathbf{C}$ \\
\hline $\mathrm{Ca}$ & $2.65 \pm 0.09$ & $0.51 \pm 0.04$ & $2.14 \pm 0.31$ \\
$\mathrm{Mg}$ & $4.16 \pm 0.07$ & $6.34 \pm 0.97$ & $5.96 \pm 1.12$ \\
$\mathrm{Na}$ & $17.36 \pm 2.64$ & $18.17 \pm 0.95$ & $16.96 \pm 1.96$ \\
$\mathrm{~K}$ & $13.90 \pm 0.94$ & $11.83 \pm 1.56$ & $12.46 \pm 1.54$ \\
$\mathrm{Fe}$ & $0.22 \pm 0.01$ & $0.77 \pm 0.15$ & $0.69 \pm 0.26$ \\
$\mathrm{P}$ & $46.70 \pm 12.80$ & $37.96 \pm 5.74$ & $45.44 \pm 10.03$ \\
Total ash $(\%)$ & $2.05 \pm 0.03$ & $1.89 \pm 0.06$ & $2.37 \pm 0.44$ \\
\hline
\end{tabular}

The results in table (2) indicated that the lowest mean value of ash content was produced by burger, B-plant $(1.89 \%)$ followed by the burger of A $(2.05 \%)$, while the highest mean value was reported by the burger of C-plant $(2.37 \%)$. The data obtained revealed that there were no significant different in ash content. It's reported that the binder, extender and other ingredients of meat products increase the ash content. The results in table (2) indicated that the highest mean value of $\mathrm{Ca}$ content was produced by burger-A (2.14), while the lowest mean value of $\mathrm{Ca}$ recorded by burger-B samples (0.51). These results are in agreement with similar studies [13], they reported that; the amount absorbed by $\mathrm{Ca}$ is depended on source, intestinal $\mathrm{PH}$, feed levels of $\mathrm{Ca}$. The $\mathrm{Mg}$ content from table (2) showed significant deference between $\mathrm{A}, \mathrm{B}$ and $\mathrm{C}$, but there where no significant deference for $\mathrm{Na}$ and $\mathrm{K}$ content. The larger amount of soy bean added to the burger produced by modern processing plants $\mathrm{A}$, has three-fold effect, raising the protein and phosphorus content, tables (1 and 2) but however it lowered the iron content $(0.22)$, which is an adequate amount regarding the daily uptake of iron necessary for humans.

Table 3. Mean values of fatty acids ( $\mathrm{mg} / 100 \mathrm{~g})$ in burger for the three processing plants.

\begin{tabular}{llll}
\hline \multirow{2}{*}{ Fatty acid } & \multicolumn{3}{l}{ Type of burger processing plants } \\
\cline { 2 - 4 } & $\mathbf{A}$ & $\mathbf{B}$ & $\mathbf{C}$ \\
\hline Butyric acid & 1.9 & 0.0 & 0.0 \\
Undecanoic acid & 0.25 & 0.0 & 0.0 \\
Myristoleic acid & 0.87 & 1.37 & 0.86 \\
Myristic acid & 1.86 & 1.01 & 2.26 \\
Palmitoleic acid & 6.81 & 13.66 & 5.12 \\
Palmatic acid & 19.40 & 11.89 & 12.49 \\
Heptadecanoic acid & 14.62 & 0.17 & 16.85 \\
Oleic acid & 43.17 & 22.78 & 18.50 \\
Stearic acid & 4.63 & 0.0 & 0.0 \\
Eicosenic acid & 0.54 & 0.38 & 0.0 \\
Linolenic acid & 3.68 & 23.18 & 33.59 \\
Eliadic acid & 0.99 & 21.43 & 0.0 \\
Lauric acid & 0.03 & 0.33 & 0.69 \\
Arachidic acid & 0.0 & 1.47 & 0.83 \\
Pentadecanoic acid & 1.36 & 2.35 & 6.76 \\
\hline
\end{tabular}

The results of the fatty acids analysis presents in table (3) indicate that the highest mean value of butyric $\mathrm{C} 4: 0$ acid was reported by A (1.90), but not detected in B, C. the same was observed for undecanoic acid C11:0 (0.25). The highest value of palmatic acid C16:0 was reported by A (19.40) followed by C and B (12.49, 11.889) respectively, this fatty acid accounts for most of the cholesterolraising activity from beef and beef products thereby increasing the risk of cardiovascular disease and stroke [14]. The results also revealed high mean value of heptadecanoic acid C17:0 in sample produced by $\mathrm{C}(16.85)$ followed by A (14.62) and the lowest was obtained by B sample (0.17). Heptadecanoic acid can build up in membrane lipids of nervous tissue, resulting in altered myelin integrity, leading eventually to impaired nervous system functioning [15]. The table (3) also recorded a highest mean value of oleic acid C18:0, which is the most abundant fatty acid in beef meat. The burger A recorded (43.17) followed by $B$ and $C$ with $(22.78,18.50)$ respectively. This result is in agreement with [16]; who reported that; oleic acid is a primary monounsaturated fatty acid in beef and accounts for about $33 \%$ of the fatty acid in beef. Stearic acid C18:0 was found only in sample produced by A, stearic acid is essentially neutral in its effects on serum total cholesterol [17]. The highest value linolenic acid $\mathrm{C} 18: 3$ found in samples produced byC (33.59) followed by $\mathrm{B}$ (23.18) and the lowest value reported by A (3.68). Linolenic acid has beneficial effect for patients suffering from cardiovascular disease [18]. Generally, the results obtained by table (3) showed that saturated fatty acids are the main acids found in beef burger produced in different processing lines A, B and C. meat products are seen to be major source of fat and provide high amount of saturated fatty acids and cholesterol, which are associated with various diseases, cardiovascular disease, obesity, hypertension and coronary 
heart disease [19].

\section{Conclusion}

In order to achieve a healthy beef burger, the animal fat content should be reduced to appropriate limits and increase the levels of other substances with beneficialproperties such as vegetable oil. The replacement of animal fat by vegetable oil has a positive effect on consumer health due they are free of cholesterol and have a higher ratio of unsaturated fatty acids. The amount of soy bean should also be increased to an adequate level to increase the protein content of the beef burger. The current study has shown that beef burger is good source of minerals essential for good human health.

\section{References}

[1] Purchas R, Zou M, Pearce P, Jackson F. Concentrations of vitamin D3 and 25-hydroxyvitamin D3 in raw and cooked New Zealand beef and lamb. Journal of Food Composition and Analysis.2007, 20, (2): 90-98.

[2] Purchas RW, Busboom JR. The effect of production system and age on levels of iron, taurine, carnosine, coenzyme Q10, and creatine in beef muscles and liver. Meat Science. 2005, 70, (4): 589-596.

[3] Voet D, Voet JG. Biochemistry. Fourth edition. 2011. JOHN WILEY \& SONS, INC. USA

[4] Pearson AM, and Gillett TG. Processed Meats. Gaithersburg, Md.: Aspen, 1999.

[5] Heinz G, Hautzinger P. 2007. Meat processing technology for small to medium scale production. FAO regional office of Asia and pacific. Bangkok.

[6] Kanner J, Kinsella J. Lipid deterioration initiated by phagocytic cells in muscle foods: beta.-carotene destruction of a myeloperoxidase-hydrogen peroxide-halide system. Journal of Agricultural and Food Chemistry, 1983, 31 (2): 370-376

[7] ICMSF international commition on microbiology criteria for food. 1988. Microorganisms in food. Application of hazard microbiological safety and quality. Blackwell scientific. Oxford.

[8] Pérez-Palacios T, Ruiz J, Martín D, Muriel E, Antequera T. Comparison of different methods for total lipid quantification in meat and meat products. Food chemistry. 2008. 110: 10251029.
[9] A. O. C. S., 1985. The Official and Tentative Methods of the American Oil Chemists, Soc., 14th ed., Pub. By American Oil Chemists, Society, 508 South Street, Champaign, Illinois 61820, USA.

[10] A. O. A. C. 1995. Official methods of analysis. Association of official analytical chemists. $16^{\text {th }}$ edition. Washington D.C. USA.

[11] Uddin ABM H, Khalid RS, Alaama M, Abdualkader AM, Kasmuri A, Abbas SA. Comparative study of three digestion methods for elemental analysis in traditional medicine products using atomic absorption spectrometry. Journal of Analytical Science and Technology. 2016, 7-6.

[12] Mahmoud KA, Badr HM. Quality characteristics of gamma irradiated beef burger formulated with partial replacement of beef fat with olive oil and wheat bran fibers. Food and Nutrition Sciences. 2011, 2, 655-666.

[13] Hays VW, Swenson MJ. 1985. Minerals and Bones. In: Dukes' Physiology of Domestic Animals, Tenth Edition. 449466.

[14] Nicolosi RJ, Wilson TA, Rogers EJ and Kritchevsky D. Effects of specific fatty acids (8:0,14:0, cis-18:1, trans-18:1) on plasma lipoproteins, early atherogenic potential, and LDL oxidative properties in the hamster. The Journal of Lipid Research. 1998, 39, 1972-1980.

[15] Frenkel EP, Kitchens RL and Johnston JM.The Effect of Vitamin B12 Deprivation on the Enzymes of Fatty Acid Synthesis. The Journal of Biological Chemistry. 1973, 248, 7540-7546.

[16] Denke MA. Role of beef and beef tallow, an enriched source of stearic acid, in a cholesterol-lowering diet. American Journal of Clinical Nutrition. 1994, 60, (6): 1044S-1049S

[17] Grundy SM. Influence of stearic acid on cholesterol metabolism relative to other long-chain fatty acids. American Journal of Clinical Nutrition. 1994, 60, (6): 986S-990S.

[18] Ascherio A, Rimm EB, Giovannucci EL, Spiegelman D, Stampfer M, Willett WC. Dietary fat and risk of coronary heart disease in men: cohort follow up study in the United States. British Medical Journal. 1996, 13; 313 (7049):84-90.

[19] Bowe B, Xie Y, Xian H, Balasubramanian S, Al-Aly Z. Low levels of high-density lipoprotein cholesterol increase the risk of incident kidney disease and its progression. Kidney international. 2016. 89, (4): 886-896. 